\title{
Career Decision-Making Profiles of Adolescents in Cyprus
}

\author{
Georgallidou Vasoula $^{1 *}$ and Dimitriou Loucia ${ }^{2}$ \\ ${ }^{1} \mathrm{PhD}$ candidate, School of Education and Social Sciences, University of Frederick, Cyprus \\ ${ }^{2}$ Associate Professor in Psychology, School of Education and Social Sciences, University of \\ Frederick, Cyprus
}

\begin{tabular}{|c|c|}
\hline ARTICLE INFO & ABSTRACT \\
\hline $\begin{array}{l}\text { Keywords: } \\
\text { Career Assessment } \\
\text { Career Counselling } \\
\text { Career Decision-making } \\
\quad \text { process } \\
\text { Secondary Education }\end{array}$ & $\begin{array}{l}\text { The purpose of the present study is to examine the career decision- } \\
\text { making profile of the adolescent students of the public high schools } \\
\text { of Cyprus by applying the Career Decision-Making Profiles (CDMP) } \\
\text { questionnaire of Gati, Landman, Davidovitch, Peretz-Asulin, \& } \\
\text { Gadassi (2010). The development of the CDMP suggests that an } \\
\text { individual's career decision making process can be better described } \\
\text { by a multidimensional profile instead of a single decision-making } \\
\text { style or a dominant characteristic. Using the data of } 421 \text { students, } \\
\text { who were about to make a career choice, the results of the survey } \\
\text { revealed eight dimensions for the Greek-Cypriot version of CDMP } \\
\text { scale. The findings construct a multidimensional profile } \\
\text { characterization of an individual's career decision making processes: } \\
\text { (1) "Information gathering and processing-Effort invested in the } \\
\text { process", (2) "Desire to please others-Dependence on others", (3) } \\
\text { "Speed of making the final decision", (4) "Consulting with others", } \\
\text { (5) "Aspiration for an ideal occupation", (6) "Locus of control", (7) } \\
\text { "Willingness to compromise", (8) "Procrastination". Using the T- } \\
\text { test, we will discuss significant gender differences in the eight } \\
\text { dimensions of the CDMP. }\end{array}$ \\
\hline
\end{tabular}

\section{Introduction}

In our days, due to significant changes in societies such as the rapid development of technology, the changes in communication, the unstable labour market, even the changes in family structure, career guidance has an important role to play in the career decision-making process of an individual. Career guidance needs to operate both at a preventive-developmental level, through the provision of information and guidance, and at a therapeutic level as well (Amundson et al., 2009). Within this context, and given that deciding on a career path is included among the most important decisions that one has to make, (Gati \& Tal, 2007), the effectiveness of career counsellors in the counselling procedure and the individual's career decision making profile awareness must be reinforced. The educational and career path choice can influence one's lifestyle (Super 1980), as well as their economic and social level (Gati \& Tal, 2007) while it may even affect their psychological well-being (Hackett, 1995). Taking into account the above, the present study aims to validate the Greek-Cypriot version of the Career Decision-Making Profiles (CDMP) questionnaire of Gati, Landman, Davidovitch, PeretzAsulin, \& Gadassi (2010), in order to examine the career decision-making approach of adolescent students attending the public junior high schools of Cyprus. 


\subsection{The CDMP and its importance in the career-building procedure}

Significant theories and models have been developed in recent decades in an attempt to interpret the behaviour, the difficulties, the stages and the particular characteristics of an individual's educational and career decision-making process. Through this plethora of researches, a common conclusion has been confirmed, that the educational and career decision making process is related to the influence of various "internal" and "external" factors (Betz \& Voyten, 1997; Creed \& Patton, 2003a; Gati, Krausz \& Osipow, 1996; Taylor \& Betz, 1983; Taylor \& Popma, 1990; Lent, Brown \& Hackett 1994, 2000, Amir \& Gati, 2006; Gati et al., 2010). It has also been revealed that the individual's career decision-making process may be better characterised by a combination of styles instead of a "dominant type" approach (Gati et al., 2010, 2012, 2014). Thus, in this context, Gati and his associates (2010) developed the Career Decision Making Profile scale, proposing that this model will allow a more accurate and comprehensive appraisal of the individual's approach to career decision-making. This tool will help the individuals who are about to make a career decision, to become aware of their career decision making profile, while counselors can better facilitate the career counseling procedure and increase its effectiveness (Gati et al., 2010, 2014).

This multidimensional model was developed to tackle the limitations of previous concepts, which were criticized for not being able to fully capture the complicated approach to the individual's career decision-making process (Gati et al., 2010) such as for example the concept of career decision-making styles of Harren, (1979), Walsh (1987), Arroba (1978), which categorized individuals into different types based on their

most dominant decision-making style. However, this concept and its inability to adapt to all the different career decision-making approaches across the different situations that an individual may face, led the researchers to move onto analyzing the individual's unique way of making career decisions through the career decision-making "profile" (Gati et al., 2010) since the previous concepts did not reflect the dynamic nature of the career decision-making process, even those that argued that individuals have a secondary style (Driver, Brousseau, \& Hunsaker, 1990; Payne, Bettman,\& Johnson, 1993). The proposed career decision-making "profiles" instead of career decision-making "styles", highlights the several factors that are required to adequately characterize the way in which individuals make decisions and reveals that both personality and situational influences reflect on the decision-making behaviour (Gati et al., 2010, 2012).

\subsubsection{The CDMP dimensions}

The model of Gati et al. (2010) suggests the use of 11 profiles for 11 different decision dimensions based on the assumption that individuals may be described more accurately as using a combination of approaches to career decision-making. The 11 dimensions are the following:

1. Information gathering (comprehensive vs. minimal) - the degree to which individuals are meticulous and thorough in collecting and organizing information.

2. Information processing (analytic vs. holistic) - the degree to which the individual analyzes information into its components, and processes the information according to these components.

3. Locus of control (internal vs. external) - the degree to which individuals believe they control their occupational future and feel that their decisions affect their career opportunities, or that these are mainly determined by external forces such as fate or luck.

4. Effort invested in the process (much vs. little) - the amount of time and mental effort individuals invest in the decision-making process.

5. Procrastination (high vs. low) - the degree to which the individual avoids or delays beginning or advancing through the career decision-making process. 
6. Speed of making the final decision (fast vs. slow) - the length of time individuals need to make their final decision once the information has been collected and compiled.

7. Consulting with others (frequent vs. rare) - the extent to which individuals consult with others during the different stages of the decision process.

8. Dependence on others (high vs. low) - the degree to which individuals accept full responsibility for making their decision (even if they consult with others), as opposed to expecting others to make the decision for them.

9. Desire to please others (high vs. low) - the degree to which the individual attempts to satisfy the expectations of significant others (e.g., parents, partner, friends).

10. Aspiration for an ideal occupation (high vs. low) - the extent to which individuals strive for an occupation that is perfect for them.

11. Willingness to compromise - the extent to which individuals are willing to be flexible about their preferred alternative when they encounter difficulties in actualizing it.

\section{The Study}

The goal of the present study is to test the multidimensional structure of the CDMP in the Cypriot society using the exploratory factor analysis on the responses of 421 students who filled out the Greek version of the questionnaire as adjusted and translated in the Greek language by Sidiropoulou et al. (2011) for the needs of the Greek society. The data was collected from 421 adolescent students, 169 boys and 252 girls, mean age of $14-15$ years old. All participants were attending the final class of junior high school and they were about to take their first mandatory educational decision before entering the high school or the vocational school education. The sample presented in this study was collected from the public schools of the four main cities in Cyprus and the rural areas. The percentage of the students attending the last class of the junior high schools in Cyprus was 7.649, as per the statistical service of Cyprus for the academic year in which the research was carried out (Ystat., 2017). The specific sample was chosen because, as mentioned above, during this period the students are obligated to make their first career educational decision which may also greatly affect their future career decision making process. Moreover, during this period, the individuals are in the early stages of forming their interests, abilities (Ginzberg, 1972) and career goals (Super, 1963), while at the same time each showing different levels of readiness in making the appropriate educational and career choices (Super et al., 1996).

The research was conducted during the academic year 2018-2019. The provision of the questionnaire was carried out by the researcher with appropriate permission from the Cyprus Ministry of Education and Culture, from each headmaster/tress of the schools that participated in the study, as well as from the participating students' parents through their written consent. The researcher explained to the students that the participation was optional and that all the questionnaires were anonymous. In the cases where students faced a problem completing the questionnaire, all the appropriate clarifications were given. The completion duration of the questionnaire was about 30 minutes.

The Career Decision Making Profile Questionnaire (CDMP) by Gati et al. (2010) was applied in the present study in order to investigate the multidimensional profile of the individual's career decision-making process. The CDMP includes 36 statements. For each statement, the participants were asked to rate on a 7-point Likert-type scale the degree to which they agreed with each statement (1- do not agree at all, 7- agree very much). The tool includes one warmup item: "I am currently concerned about my future field of study or occupation' and two validity statements "I try to choose the option that is best for me", "It makes no difference to me what career I will have in the future". These statements, as Gati et al. (2010) suggest, were included to ensure that the participants' answers came after reading the items carefully and gave their responses adequate consideration. The remaining 33 statements represented one of 
the two poles of each of the 11 dimensions of the CDMP. The study of Gati et al. (2010) showed that the CDMP had acceptable internal consistency reliability, the median Cronbach a of the 11 dimensions was .81 and the 2-week test-retest median reliability was .82 (range: .76 to .86).

\section{Results of the Research}

An exploratory factor analysis was carried out for the CDMP scale, for the needs of the Cypriot society. The analysis revealed eight profiles for eight different decision dimensions with an eigen-value above 1 . Thirty-one statements/items loaded on the eight dimensions. The percentage of variance explained by the eight dimensions was $60.31 \%$. The means of the eight dimensions indicate appropriate within-dimension variance. The reliabilities of the scale varied from .66 to .80 . Only the reliability of the dimension "Procrastination" was .60 showing that the counsellor must be careful during its exploitation in the career counselling process.

The items have been reversed as per Gati's instructions so all items of the scale represent the same pole of the dimensions and then the mean ratings of the items representing each dimension were computed. Two statements/items were dropped (items 2 and 15 of the questionnaire) as they did not load with the expected dynamic to the dimensions. It is possible that the complex content of these two statements, based on the given translation, may not be fully understood by this particular group because of their young age, although this problem was not apparent in the pilot study.

\subsection{The eight extracted dimensions}

1. Desire to please others-Dependence: the degree to which the individual's attempts to satisfy the expectations of significant others (e.g., parents, friends) and the degree to which one wants to avoid the responsibility for making their own decision and expects others to make the decision for them.

2. Information gathering and processing-Effort invested in the process: the degree to which the individual collects, organizes and analyzes information into its components and the amount of time and mental effort they invest in the decision-making process.

3. Speed of making the final decision: the length of time the individual needs to make their final decision once the information has been collected and compiled.

4. Consulting with others: the extent to which the individual consults with others during the different stages of the decision process.

5. Aspiration for an ideal occupation: the extent to which the individual strives for an occupation that is perfect for them.

6. Locus of control: the degree to which the individual believes they control their occupational future and feels that the taken decision affects their career opportunities, or that these are mainly determined by external factors such as fate or luck.

7. Willingness to compromise: the extent to which the individual is willing to be flexible about their preferred alternative when they encounter difficulties in actualizing it.

8. Procrastination: the degree to which the individual avoids or delays their involvement in the career decision-making process.

Table 1 presents all thirty-one query loads and the eight extracted dimensions. 
Table 1

Dimensions loadings (principal component method) via the use of explanatory factor analysis.

\begin{tabular}{|c|c|c|c|c|c|c|c|c|}
\hline \multirow{2}{*}{ Statements } & \multicolumn{8}{|c|}{ Dimensions } \\
\hline & D1 & $\mathrm{D} 2$ & D3 & D4 & D5 & D6 & D7 & D8 \\
\hline $\begin{array}{l}\text { 21. I do not want to make the decision alone; I } \\
\text { want to share the responsibility with others. }\end{array}$ & .733 & -.046 & .037 & -.161 & -.165 & .099 & .026 & .106 \\
\hline $\begin{array}{l}\text { 22. I will eventually choose one of the options } \\
\text { that will please the people closest to me. }\end{array}$ & .722 & .022 & .025 & .169 & -.097 & .182 & .088 & .017 \\
\hline $\begin{array}{l}\text { 34. The expectations of those closest to me are } \\
\text { the most important factor in my decision. }\end{array}$ & .717 & .110 & .052 & .049 & .055 & .018 & .037 & 188 \\
\hline $\begin{array}{l}\text { 10. Consider it important to choose the option } \\
\text { that will satisfy my family and close friends. }\end{array}$ & .713 & -.061 & .067 & .146 & -.003 & .082 & .173 & -.059 \\
\hline $\begin{array}{l}\text { 33. I prefer that other people share the } \\
\text { responsibility for my decision. }\end{array}$ & .685 & .041 & -.119 & -.196 & -.161 & .180 & -.005 & .263 \\
\hline $\begin{array}{l}\text { 9. In an important decision like choosing an } \\
\text { occupation, I want someone else to decide for me. }\end{array}$ & .494 & -.191 & .278 & -.097 & -.050 & .181 & -.087 & .097 \\
\hline $\begin{array}{l}\text { 14. I usually make my decisions after comparing } \\
\text { several characteristics of the alternatives. }\end{array}$ & .005 & .754 & .033 & -.066 & .080 & .009 & -.015 & -.097 \\
\hline $\begin{array}{l}\text { 26. I usually compare the alternatives by } \\
\text { considering their advantages and disadvantages. }\end{array}$ & -.041 & .749 & .086 & -.048 &, 030 & -.117 & .012 & -.071 \\
\hline $\begin{array}{l}\text { 17. I immerse myself entirely in the decision- } \\
\text { making process. }\end{array}$ & .061 & .688 & .031 & -.048 & .220 & -.023 & .041 & -.120 \\
\hline $\begin{array}{l}\text { 29. When I need to make a decision, I invest } \\
\text { a lot of time and effort in it. }\end{array}$ & .001 & .685 & .225 & -.006 & .043 & -.098 & .010 & .167 \\
\hline $\begin{array}{l}\text { 5. I invest a lot of effort in the decision-making } \\
\text { process. }\end{array}$ & -.076 & .519 & .293 & . 087 & . 144 & .031 & .163 & -.151 \\
\hline $\begin{array}{l}27 \text {. I usually do not try to collect all available } \\
\text { information about the occupations I am considering. }\end{array}$ & .364 & -.445 & .097 & .411 & .009 & .038 & .072 & .053 \\
\hline $\begin{array}{l}\text { 18. Even after I have collected the relevant } \\
\text { information, it takes me a lot of time to } \\
\text { make my final decision. }\end{array}$ & .158 & .290 & .776 & -.042 & . 027 & .062 & .104 & .061 \\
\hline $\begin{array}{l}\text { 6. Even after I have all of the necessary } \\
\text { information, I need a long time to make a decision. }\end{array}$ & .063 & .127 & .723 & -.014 & .006 & .119 & .020 & 186 \\
\hline $\begin{array}{l}\text { 30. When I get to the final stage of making a } \\
\text { decision, I hesitate quite a bit. }\end{array}$ & .105 & .379 & .709 & -.004 & .034 & -.046 & .016 & .241 \\
\hline 19. I tend to put off my career decision-making. & .071 & .115 & $\begin{array}{l}- \\
.677\end{array}$ & .294 & .236 & .019 & -.070 & .071 \\
\hline $\begin{array}{l}\text { 20. I do } \\
\text { right dec }\end{array}$ & -.147 & -.050 & -.100 & .763 & .110 & -.025 & .035 & .076 \\
\hline $\begin{array}{l}\text { 32. I usually do not consult with other people when } \\
\text { making my decision. }\end{array}$ & .032 & .006 & -.100 & .756 & .052 & .004 & .021 & .056 \\
\hline $\begin{array}{l}\text { 8. I usually consider my choices and make my } \\
\text { decisions without consulting others. }\end{array}$ & .052 & -.058 & -.039 & .741 & -.062 & .112 & .057 & .080 \\
\hline d the occupation that $w$ & -.017 & .130 & -.073 & .074 & .826 & -.027 & -.025 & -.043 \\
\hline $\begin{array}{l}\text { 11. I believe that I can find a perfect occupation that } \\
\text { will satisfy all my wishes. }\end{array}$ & -.064 & .130 & -.030 & .113 & .791 & .072 & -.020 & -.014 \\
\hline $\begin{array}{l}\text { 35. I believe that I can find an occupation that will } \\
\text { satisfy all my aspirations. }\end{array}$ & -.193 & .117 & .017 & -.079 & .734 & -.075 & .027 & .034 \\
\hline $\begin{array}{l}\text { 16. Factors outside of my control (like fate) greatly } \\
\text { influence my career choice and its outcomes. }\end{array}$ & .123 & -.032 & .051 & .039 & -.051 & .825 & .078 & .104 \\
\hline $\begin{array}{l}\text { 4. I am not solely responsible for the results of my } \\
\text { decisions; fate and luck greatly affect my future } \\
\text { career. }\end{array}$ & .213 & -.034 & -.039 & -.072 & .037 & .785 & .039 & .211 \\
\hline $\begin{array}{l}\text { 28. It really doesn't matter what I choose; fate will } \\
\text { ultimately influence my future career anyway. }\end{array}$ & .212 & -.147 & .131 & .179 & -.008 & .684 & .076 & -.053 \\
\hline $\begin{array}{l}\text { 12. If I am not accepted for my first-choice major or } \\
\text { training program, I will compromise and opt for my } \\
\text { second-choice. }\end{array}$ & .071 & .161 & -.018 & .034 & .019 & .015 & .825 & .003 \\
\hline $\begin{array}{l}\text { 36. If I am not able to enter a degree program in my } \\
\text { chosen filed, I will compromise and look for another } \\
\text { one that is right for me. }\end{array}$ & .010 & .090 & .080 & .000 & . 096 & .083 & .804 & .088 \\
\hline $\begin{array}{l}24 \text {. If I can't realize my first-choice, I will be willing } \\
\text { to compromise. }\end{array}$ & .164 & -.175 & .107 & .119 & -.176 & .087 & .607 & .044 \\
\hline 7. I tend to postpone my career decision. & .158 & -.061 & .143 & .079 & -.033 & .116 & -.017 & .763 \\
\hline $\begin{array}{l}\text { 31. I tend to postpone the decision-making process } \\
\text { as much as I can. }\end{array}$ & .099 & -.120 & .137 & .062 & -.021 & .059 & .099 & .757 \\
\hline $\begin{array}{l}\text { 3. Generally, I am thorough in gathering } \\
\text { information. }\end{array}$ & .228 & -.073 & .038 & .295 & . 049 & .109 & .081 & .427 \\
\hline
\end{tabular}


As Table 2 shows, the analysis of the means of the eight dimensions of CDMP revealed the highest scores for the dimensions "Information gathering and processing-Effort invested in the process" $(M=5.06)$, "Aspiration for an ideal occupation" $(M=5.57)$, "Locus of control" $(M=5.10)$ and "Consulting with others" $(M=4.66)$. More moderate scores were for "Procrastination" $(\mathrm{M}=4.40)$, "Willingness to compromise" $(\mathrm{M}=3.86)$ and "Speed of making the final decision" $(\mathrm{M}=3.34)$. The lowest score was for "Desire to please others-Dependence" $(\mathrm{M}=2.81)$.

Table 2.

Descriptive statistics for the eight dimensions of the Career Decision-Making Profile scale.

\begin{tabular}{|c|c|c|c|c|c|c|}
\hline Dimension & $\mathrm{N}$ & Mean & Median & S.D. & Min. & Max. \\
\hline Desire to please others-Dependence & 421 & 2.81 & 2.67 & 1.22 & 1.00 & 6.33 \\
\hline Information gathering and processing- Effort invested in the process & 421 & 5.06 & 5.17 & 1.02 & 1.67 & 7.00 \\
\hline Speed of making the final decision & 421 & 3.34 & 3.25 & 1.42 & 1.00 & 7.00 \\
\hline Consulting with others & 421 & 4.66 & 4.67 & 1.48 & 1.00 & 7.00 \\
\hline Aspiration for an ideal occupation & 421 & 5.57 & 5.67 & 1.21 & 1.00 & 7.00 \\
\hline Locus of control & 421 & 5.10 & 5.33 & 1.39 & 1.00 & 7.00 \\
\hline Willingness to compromise & 421 & 3.86 & 4.00 & 1.48 & 1.00 & 7.00 \\
\hline Procrastination & 421 & 4.40 & 4.33 & 1.37 & 1.00 & 7.00 \\
\hline
\end{tabular}

\subsection{Gender differences among the dimensions}

Table 3 presents the t-test for the eight CDMP dimensions between gender categories. The analysis revealed differences in the mean scores among the eight dimensions. In five dimensions the gender differences were statistically significant at a 5\% of lower level of significance. Specifically, the mean vale of males was statistical significant and higher $(\mathrm{M}=2.96, \mathrm{~S} . \mathrm{D} .=1.22)$ than females $(\mathrm{M}=2.71, \mathrm{~S} . \mathrm{D} .=1.22),(\mathrm{t}(419.00)=2.03, \mathrm{p}=.043)$ for "Desire to please others-Dependence". Males also reported significantly higher levels $(\mathrm{M}=3.52$, S.D.=1.30) in "Speed of making the final decision" than females $(M=3.22$, S.D.=1.49), $(\mathrm{t}(419.00)=2.10, \mathrm{p}=.036)$. In the same approach, the analysis revealed males' $\mathrm{s}$ score higher $(\mathrm{M}=5.72$, S.D.=1.04) for "Aspiration for an ideal occupation" than females $(\mathrm{M}=5.46$, S.D.=1.31 $),(\mathrm{t}(407.53)=2.26, \mathrm{p}=.025)$. Females' scores were higher $(\mathrm{M}=4.83$, S.D. $=1.51)$ than males' scores $(\mathrm{M}=4.40$, S.D. $=1.40),(\mathrm{t}(419,00)=-2.99, \mathrm{p}=.003)$ for "Consulting with others". Females also reported significantly higher levels $(M=4.54$, S.D. $=1.39)$ than males $(M=4.18$, S.D.=1.30), $(\mathrm{t}(419.00)=-2.69, \mathrm{p}=.007)$ for "Procrastination". These differences suggest that males attempt to satisfy more the expectations of significant others (e.g., parents, friends) while they tend to avoid the responsibility for making their own decision and expect others to make the decision for them. They tend to strive more for an occupation that is perfect for them and come to a final decision faster than females. On the other hand, the differences suggest that the females consult more with others and they tend to delay the beginning of the career decisionmaking process more than males.

Table 3

Independent sample t-test for the eight dimensions of the Career Decision-Making Profile scale between gender categories.

\begin{tabular}{|c|c|c|c|c|c|c|c|}
\hline & \multicolumn{2}{|c|}{ Male $(n=169)$} & \multicolumn{2}{|c|}{ Female $(n=252)$} & \multirow{2}{*}{$\mathrm{t}$} & \multirow{2}{*}{ d.f. } & \multirow{2}{*}{$\mathrm{P}$} \\
\hline & Mean & S.D. & Mean & S.D. & & & \\
\hline Desire to please others-Dependence. & 2.96 & 1.22 & 2.71 & 1.22 & 2.03 & 419.00 & 0.043 \\
\hline Information gathering \&proc.-Effort invested. & 5.05 & 0.89 & 5.08 & 1.09 & -0.31 & 402.60 & 0.758 \\
\hline Speed of making the final decision. & 3.52 & 1.30 & 3.22 & 1.49 & 2.10 & 419.00 & 0.036 \\
\hline Consulting with others. & 4.40 & 1.40 & 4.83 & 1.51 & -2.99 & 419.00 & 0.003 \\
\hline Aspiration for an ideal Occupation. & 5.72 & 1.04 & 5.46 & 1.31 & 2.26 & 407.53 & 0.025 \\
\hline Locus of control. & 5.07 & 1.39 & 5.12 & 1.39 & -0.30 & 419.00 & 0.765 \\
\hline Willingness to compromise & 3.96 & 1.39 & 3.79 & 1.53 & 1.12 & 419.00 & 0.264 \\
\hline Procrastination & 4.18 & 1.30 & 4.54 & 1.39 & -2.69 & 419.00 & 0.007 \\
\hline
\end{tabular}




\section{Discussion and Conclusion}

The proposed multidimensional model, suggests that individuals may adopt more than one behaviour at the same time to describe their career decision-making. Based on that, and the findings of the research, using the CDMP scale for the needs of the Cypriot society, the statistical analysis revealed eight dimensions and thirty-one items to be loaded on them. The dimensions are: "Information gathering and processing- Effort invested in the process", "Aspiration for an ideal occupation", "Locus of control", "Consulting with others", "Procrastination", "Willingness to compromise", "Speed of making the final decision", "Desire to please others-Dependence". The differences between the dimensions of the present study and the original one are observed in the following dimensions: The dimension of the present study "Information gathering and processing-Effort invested in the process" represents three separate dimensions ("Information gathering", "Information processing", "Effort invested in the process") in the original scale, and the dimension of the present study, "Desire to please others-Dependence", in the original scale represents two separate dimensions ("Desire to please others", "Dependence on others"). This merging does not diminish the value of the tool as the eight extracted factors simply describe the manufacturer's factors in a more economical structure and format. This emergence of dimensions is also observed in the Greek version of CDMP whereas the exploratory factor analysis revealed seven factors (Sidiropoulou et al., 2011) compared to the eight of the present research.

The statistical analysis of our data also revealed that the highest scores were observed in the means of the dimensions "Information gathering and processing- Effort invested in the process", "Aspiration for an ideal occupation", "Locus of control" and "Consulting with others". More moderate scores were observed in "Procrastination", "Willingness to compromise" and "Speed of making the final decision". The lowest score was for "Desire to please others-Dependence". The high importance that students attach to the "Aspiration for an ideal occupation" may be related to the young age of the students (14 to 15 years) and can be interpreted through the theoretical framework of evolutionary theories (Super, 1963; Ginzberg \& et al., 1951, 1972) that argue that the young person at this age starts to crystallize their interests, skills and abilities, thus the exploration of the ideal occupation is consequential. Also, another possible explanation for this, may be the great concern of individuals about finding an "ideal" occupation that will help them cope successfully with the difficulties of the economical crisis by remaining flexible and adaptable in the competitive labour market (Savickas, 2012). High scores have also been observed in the means of the dimensions "Information gathering and processing-Effort invested in the process", and "Consulting with others". The students, despite of their young age, face the challenge of making a decision with a high sense of severity by gathering and processing information, showing great effort in their educational and career choices while they accept guidance and advice. These findings are positive elements of the specific target group as they show the high degree of engagement in career issues. In addition, the high score in the mean of the dimension "Locus of control" reveals that students attending the junior high school believe that they have control over their career future and believe that the decisions they make affect their future career opportunities. These findings correlate with low rating in the mean of the dimension "Desire to please others-Dependence". The low rating in the mean of this dimension, shows that the students do not seek to please significant others but instead, try to make decisions on their own. This reveals their potential for seeking advice, and exploring their educational and career choices. Finally, the average performance of the scoring for the means of the dimensions "Procrastination" and "Speed of making the final decision" show that junior high school students are moderately delaying their decision-making process. For students in this age group, there is no urgent need to make a final decision at this time, as the educational selection framework can lead to several career choices. The 
procrastination of an individual can also be related to several other factors such as lack of decision-making efficacy (Steel, 2007).

The results of the present study also revealed significant differences between the genders regarding the means of the dimensions of the CDMP scale. More specifically, scores were higher among males than females for the dimension "Desire to please others-Dependence" with the males seeking to satisfy the expectations of significant others and letting others make the decision for them at a higher degree than females. This finding is in line with the results found in surveys in Greece by Sidiropoulou et al. (2011) but also by Argyropoulou et al. (2018) and may be related to the level of the maturity of the sexes (Sidiropoulou et al., 2011). According to Drossos (2011), males seem to be more disadvantaged than females in terms of career maturity, such as in career decision making. Scores of our male participants were also higher for the dimension "Speed of making the final decision", indicating that they are faster in making decisions than females while they strive more to choose the perfect occupation. In the studies of Gati et al. (2010), Gadassi et al. (2012) it has also been observed that young males are moving faster in making a final decision than females. On the other hand, scores were higher among females than males in the dimensions "Procrastination" and "Consulting with others". Females seem to delay the beginning of their career decision-making process while they seek to consult with others more frequent than males. This finding is common with the research of Sidiropoulou et al. (2011), Gati et al. (2010), Gadassi et al. (2012) as well as with the findings that report that females have a more positive approach towards help-seeking than males (Di Fabio \& Bernaud, 2008). As has been reported in Gati et al. (2010), Gadassi et al. (2012) and Rassin \& Muris (2005) the young females delay taking the final decision since they invest more time in seeking advice.

The present findings can be generalized and could provide important information about the career decision-making approach of adolescent students of the Cypriot society, contributing to the effectiveness of the career guidance programme in secondary education. Factors that affect this decision-making, such as school performance, origin, socio-economic level of the family, could be taken into account in future research, providing a more accurate profile for the career decision-making of adolescent students.

\section{References}

Amir, T., \& Gati, I. (2006). Facets of career decision-making difficulties. British Journal of Guidance and Counselling, vol.34(4), pp.483-503.

Amundson, N. E., Harris-Bowlsbey, J.A., \& Niles, S. G. (2009). Essential Elements of Career Counseling. Athens: ЕКЕП.

Argyropoulou Catherine, Katsioula Panagiota, Drosos Nikos, Kaliris Andronikos. (2018). Career Decision-Making Profile and Courage: The case of senior high school students in

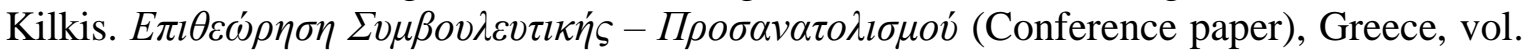
115 , pp. 23-38.

Arroba, T. Y. (1978). Decision-making style as a function of occupational group, decision content and perceived importance. Journal of Occupational Psychology, vol. 51, pp.219-26.

Betz, N.E., \& Voyten, K.K. (1997). Efficacy and outcome expectations influence career exploration and decidedness. Career Development Quarterly, vol. 46, pp.179- 189.

Creed, P. A., \& Patton, W. (2003 $\alpha$ ). Predicting two components of career maturity in schoolbased adolescents. Journal of Career Development, vol. 29(4), pp. 277-284.

Di Fabio, A., \& Bernaud, J. C. (2008). The help-seeking in career counseling. Journal of Vocational Behavior, vol 72, pp. 60-66. 
Driver, M.J., Brousseau, K.B., Hunsaker, P.L. (1990), The Dynamic Decision Maker, JosseyBass, San Francisco, CA.

Drosos, N. (2011). Career maturity and career decision making of adolescents from different cultural background. Phd Theses. National Documentation Centre. National and Kapodistrian University of Athens.

Gadassi,R., Itamar Gati, and Amira Dayan (2012). The Adaptability of Career DecisionMaking Profiles Joumal of Counseling Psychology, vol. 59, No. 4, pp. 612-622.

Gati, I., \& Tal, S. (2007). Decision-making models and career guidance. In J.A. Athanasou, R. Van Esbroeck (eds). International Handbook of Career Guidance, (115-132). Springer Science\&Business Media B.V.

Gati, I., Landman, S., Davidovitch, S., Asulin-Peretz, L., \& Gadassi, R. (2010). From Career Decision-Making Styles to Career Decision-Making Profiles: A Multidimensional Approach. Journal of Vocational Behavior, vol. 76(2), pp.277-291.

Gati, Landman, Davidovitch, Asulin-Peretz, and Gadassi (2012). Career Decision-Making Profiles of Italian Adolescents. Journal of career Assessment, vol. 20, issue: 4, pp. 375-389.

Gati Imatar and Nimrod Levin (2012). The Stability and Structure of Career Decision-Making Profiles: A 1-Year Follow-Up. Journal of Career Assessment, vol. 20 issue: 4, pp. 390-403.

Gati, I., \& Levin, N. (2014). Counseling for Career Decision-Making Difficulties: Measures and Methods. The Career Development Quarterly, vol. 62(2), pp. 98-113.

Gati, I., Krausz, M., \& Osipow, S. H. (1996). A taxonomy of difficulties in career decision making. Journal of Counseling Psychology, vol. 43(4), pp. 510-526.

Ginzberg, E., Ginsburg, S. W., Axelrad, S., \& Herma, J. L. (1951). Occupational choice: An approach to a general theory. New York: Columbia University Press.

Ginzberg, E. (1972). Toward a Theory of Occupational Choice: A Restatement. Vocational Guidance Quarterly, vol. 20(3), pp. 2-9.

Hackett, G. (1995). Self-efficacy in career choice and development. In A. Bandura (Ed.), SelfEfficacy in Changing Societies (pp. 232-259). New York: Cambridge University Press.

Harren, V. A. (1979). A model of career decision making for college students. Journal of Vocational Behavior, vol. 14, pp.119- 133.

Lent, R. W., Brown, S. D., \& Hackett, G. (1994). Toward a unifying social cognitive theory of career and academic interest, choice, and performance. Journal of Vocational Behavior, vol. 45, pp. 79-122.

Lent, R.W., Brown, S.D., \& Hackett, G., (2000), Contextual supports \& barriers to career choice: A social cognitive analysis. Journal of Counseling Psychology, vol. 47, pp. 36-49.

Payne, J. W., Bettman, J. R., \& Johnson, E. J. (1993). The adaptive decision maker. Cambridge, England: Cambridge University Press.

Rassin, E., \& Muris, P. (2005). To be or not to be indecisive: Gender differences, correlations with obsessive-compulsive complaints, and behavioural manifestation. Personality and Individual Differences, vol. 38, pp.1175-1181.

Savickas M.L., \& Profeli, E.J. (2012). Career Adapt-Abilities Scale: construction, reliability and measurement equivalence across 13 countries. Journal of Vocational Behavior, vol. 80, pp. 661-673. 
Sidiropoulou-Dimakakou, Argyropoulou Katerina, Drosos Nikos (2011). Investigation of Adolescents' career decision making profile using Career Decision-Making Profile

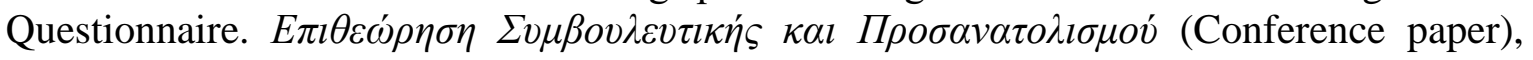
Greece, vol. 96-97, pp. 74-93.

Sidiropoulou-Dimakakou, Drosos, N. (2008). Development of Career Decision Making Skills:

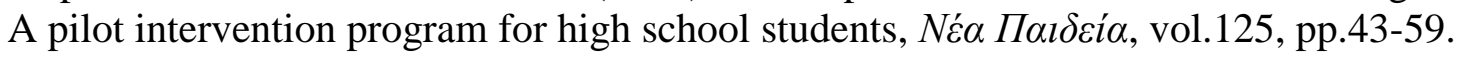

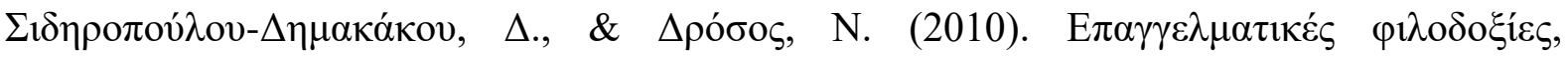

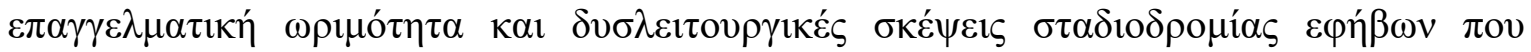

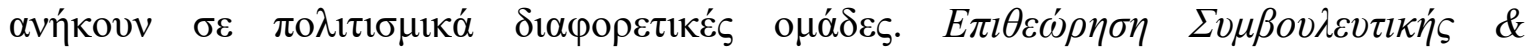

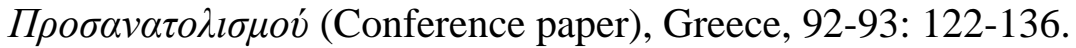

Steel, P. (2007). The nature of procrastination: A meta-analytic and theoretical review of quintessential self-regulatory failure. Psychological Bulletin, vol. 133, pp. 65-94.

Super, D. E. (1963). Career Development: Self Concept Theory. New York: C.E.E.B.

Super, D. E. (1980). A life-span, life-space approach to career development. Journal of Vocational Behavior, vol. 16(3), pp.282-298.

Super, D., Savickas, M., \& Super, C. (1996). The life-span, life-space approach to careers. In Brown, Brooks \& Associates (Eds), Career Choice \& Development, pp. 121-178, San Francisco: Jossey Bass.

Taylor, K. M., \& Betz, N. E. (1983). Applications of Self-Efficacy Theory to the understanding and treatment of career indecision. Journal of Vocational Behavior, vol. 22, pp. 63-81.

Taylor, K. M. \& Pompa, J. (1990). An examination of the relationships among career decisionmaking self-efficacy, career salience, locus of control, and vocational indecision. Journal of Vocational Behavior, vol. 37, pp. 17-31.

Walsh, D.J. (1987). Individual variations within the vocational decision-making process: A review and integration. Journal of Career Development, vol.14, pp. 52- 65.

Ystat. (2017). [Online] Available: https://www.mof.gov.cy/mof/cystat/statistics.nsf/index_ en/index_en?OpenDocument 